\title{
Tutorial Mendeley: Solusi terhadap Permasalahan dalam Penulisan
}

\author{
Junio Richson Sirait ${ }^{1}$, Hestyn Natal Istinatun ${ }^{2)}$, Marium ${ }^{3)}$ \\ Sekolah Tinggi Teologi Kadesi Yogyakarta \\ Juniorichson1995@gmail.com
}

\begin{abstract}
Abstrak
Mendeley merupakan aplikasi yang dibuat untuk menolong para penulis mensitasi karyakarya ilmiah yang dimuat dalam media online maupun cetak. Namun sebagian mahasiswa dan dosen seringkali mengalami kesulitan dalam menggunakan aplikasi tersebut. Tujuan penulisan ini untuk memberikan langkah-langkah menggunakan mendeley berserta penjelasannya. Metode yang digunakan dalam tulisan ini adalah eksposisi. Melalui tulisan ini diharapkan mahasiswa dan dosen dapat terbantu dalam menggunakan mendeley pada saat membuat karya yang berupa tulisan. Mendeley merupakan aplikasi yang direkomendasi oleh lembaga-lembaga publikasi di nasional maupun internasional.
\end{abstract}

Kata-kata Kunci: Mendeley, Sitasi, Referensi.

\section{Pendahuluan}

Mendeley adalah program yang dikembangkan oleh Elsevier ${ }^{1}$ yang dapat digunakan melalui desktop (komputer dll) dan web, yang diciptakan dengan tujuan untuk menolong para penulis dalam mengelola tulisan yang berbentuk penelitian atau jenis karya tulisan lainnya. Melalui program ini para penulis dapat menyimpan karya-karya tulisan yang menjadi referensi penulisan secara gratis di web sebesar 2 GB. Tidak hanya itu saja, para

\footnotetext{
${ }^{1}$ Elsevier adalah penyedia informasi terbesar didunia yang didirikan pada tahun 1880 . Produk yang dihasilkan meliputi jurnal The Lancet dan Cell, current opinion, jurnal elektronik ScienceDirect, seri jurnal trends dan pangkalan data sitiran daring scopus.
} 
penulis juga dapat memakai aplikasi ini dengan keadaan offline di komputer atau sejenisnya asalkan semua referensi yang terdapat di web telah di sinkronkan dengan mendeley versi desktop. Hal ini sangat memudahkan para penulis karena situasi internet tidak menjadi penghalang untuk menyelesaikan tulisan yang dibuatnya. Mendeley juga memberikan tools tersendiri secara manual untuk para penulis dalam memasukan referensi yang belum diterbitkan di media online.

Dosen, mahasiswa dan kaum terpelajar lainnya adalah pengguna terbesar aplikasi Mendeley. Tuntutan lembaga-lembaga publikasi membuat mereka harus mempelajarinya supaya setiap karya tulisnya dapat dimuat di media yang telah disediakan. Setiap lembaga pendidikan maupun pemerintah mengharuskan dosen dan mahasiswa mengadakan penelitian atau karya tulis lainnya dan mempublikasikannya ditempat-tempat publikasi yang terpercaya. ${ }^{2}$ Hal ini menjadi penting dan harus diperhatikan oleh para penulis karena banyaknya lembaga publikasi yang mempublikasikan karya tulis dengan tidak mengikuti aturan-aturan yang telah dibuat sehingga terdapat "kecurangan" dalam proses publikasi karya tulis.

Mendeley yang menjadi salah satu aplikasi ${ }^{3}$ rekomendasi lembaga publikasi kepada penulis, akan dibahas dengan rinci dan sistematis pada tulisan ini dengan harapan supaya keteraturan penulisan dapat tercapai dengan baik oleh karena adanya panduan yang memudahkan para penulis dalam menulis semua pandangannya.

\section{Metode}

Panduan aplikasi Mendeley ini disajikan dengan menggunakan metode eksposisi. Eksposisi adalah salah metode yang memiliki upaya untuk memberikan penjelasan dan informasi secara rinci dan sistematis. Langkah-langkah yang akan digunakan yaitu

\footnotetext{
${ }^{2}$ Tempat publikasi yang terpercaya menekankan bahwa adanya tempat publikasi yang tidak jelas kelembagaannya dan tempat ini haruslah dihindari oleh para penulis.

${ }^{3}$ Selain aplikasi Mendeley terdapat aplikasi lainnya yang direkomendasikan oleh lembaga publikasi yaitu Zotero (peluncuran versi terbaru bernama Zotero Standalone), EndNote dan WizFolio.
} 
menguraikan tahapan di setiap proses (install plugin, memasukan sitasi dan ferensi) dan menjelaskan proses kerja aplikasi.

\section{Pembahasan}

\section{Install Plugin}

Sebelum lebih jauh membahas tahapan ini, diharapkan semua penulis telah menginstall aplikasi Mendeley versi Web dan Desktop terlebih dahulu. Pada umumnya tahapan tersebut tidaklah menjadi pertanyaan dari permasalahan yang dialami oleh banyaknya penulis. Permasalahan yang banyak-seringkali terjadi pada tahapan menghubungkan Mendeley Desktop dengan Microsoft Word. Hal ini disebabkan karena ada banyak penulis yang belum cukup mengetahui tools-tools yang terdapat pada Mendeley sehingga mareka mengalami kesulitan dan tidak jarang juga ada yang menyerah.

Kurangnya pengalaman dalam menggunakan aplikasi-aplikasi yang kinerjanya hampir mirip dengan Mendeley telah banyak membuat perasaan mereka menyatakan bahwa mereka tidak akan dapat menemukan jalan keluar "menjadi nyata" dan sekaligus menggagalkannya dalam memecahkan permasalahan tersebut, padahal mengenai seperti itu sudah banyak panduan yang dibahas di media YouTube. Solusi untuk permasalahan tidak dapatnya Mendeley Desktop terhubung dengan Microsoft Word terletak pada bagian Install Plugin.

Setiap tahapan pada saat melakukan install plugin haruslah diperhatikan dengan baik keterangan demi keterangan saat melakukannya. Berikut tahapan-tahapan yang harus dilakukan oleh para penulis. Pertama, ${ }^{4}$ klik aplikasi Mendeley, lalu masukan email dan password $^{5}$ yang telah didaftarkan pada saat install Mendeley versi Web. Kedua, klik menu Tools dan pilih Install MS Word Plugin. Ketiga, Klik Yes. Kemudian untuk menguji apakah tahapan ini telah berhasil yaitu dengan membuka Microsoft Word, klik referensi, maka akan terlihat Mendeley pada menu ini.

\footnotetext{
${ }^{4}$ Pada tahapan ini, untuk lebih mudah penulis memberikan gambar pada bagian lampiran.

${ }^{5}$ Mengenai emai dan password pada mendeley disarankan sama dengan email dan password gmail yang dipakai. Hal ini menjadi penting agar tidak mudah lupa dan mudah untuk mengingatnya.
} 


\section{Gaya Sitasi Serta Cara Menginstall}

Aplikasi Mendeley memiliki banyak gaya sitasi. Pada kesempatan ini penulis hanya memberikan 17 gaya sitasi serta cara menginstall gaya sitasi tersebut.

\section{Gaya Sitasi}

\section{MENDELEY}

\section{CITATION STYLE}

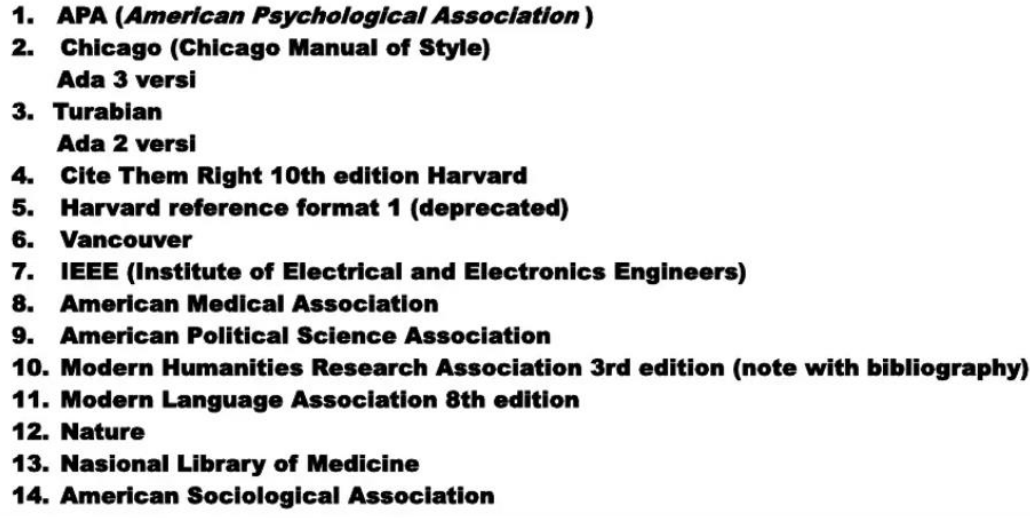

1. APA (American Psychological Association)

2. Chicago (Chicago Manual of Style) Ada 3 versi

3. Turabian Ada 2 versi

4. Cite Them Right 10th edition Harvard

5. Harvard reference format 1 (deprecated)

6. Vancouver

7. IEEE (Institute of Electrical and Electronics Engineers)

8. American Medical Association

9. American Political Science Association

10. Modern Humanities Research Association 3rd edition (note with bibliography)

11. Modern Language Association 8th edition

12. Nature

13. Nasional Library of Medicine

14. American Sociological Association

\section{Cara Menginstall}

Pada bagian menginstall gaya sitasi, penulis seringkali mengalami banyak kesalahan, secara khusus bagi yang baru memulai memakai aplikasi Mendeley. Mereka banyak menghabiskan waktu untuk bereksperimen pada aplikasi Microsoft Word, padahal penyelesaian pada bagian ini hanya terdapat pada aplikasi Mendeley Desktop. Berikut langkah-langkah untuk menginstallnya. Pertama, klik menu view, lalu arahkan kursor ke bagian Citation Style, dan klik More Style. Kedua, jika style yang diinginkan tidak ada pada bagi installed maka klik Get More Style, pada pencarian ketik style yang akan cari, setelah muncul klik tulisan tersebut lalu klik Use This Style dan terakhir klik done. 


\section{Jenis Sitasi dan Contohnya}

Jenis sitasi merupakan bagian yang sangat familiar di kalangan para penulis. Namun masih ada yang tidak memperhatikan urutan tata letak sitasi saat melakukannya secara manual (tidak menggunakan aplikasi). Jenis sitasi terbagi menjadi tiga bagian yaitu Innote/ Bodynote, Footnote, dan Endnote. Berikut jenis sitasi serta contohnya.

\section{Innote/ Bodynote}

Innote/ Bodynote juga dikenal dengan sebutan catatan tubuh yang merupakan sumber kutipan (sumber rujukan) yang letaknya berada setelah kutipan. Jenis ini biasanya hanya memperlihatkan nama, tahun dan halaman penulis. Selain hal tersebut ada juga yang hanya mencantumkan nama dan tahun saja. Berikut contoh format dari style sitasi (Gaya Sitasi) yang masuk dalam kategori innote/ bodynote.

\section{American Psychological Association}

Allah memiliki rencana besar atas manusia pada umumnya dan umat Israel secara khusus (Ristiono \& Sirait, 2021, p. 1).

\section{Footnote}

Footnote merupakan sumber kutipan yang letaknya dibawah karangan/tulisan. Jenis ini biasanya memperlihatkan nama, tahun, judul, tempat publikasi, bulan, tanggal, tahun, tanggal mengutip dan url. Namun dalam kejadian khusus jenis ini hanya memperlihatkan Ibid, Op. cit, dan Loc.cit. berikut salah satu contoh style yang masuk dalam kategori footnote.

\section{Turabian $8^{\text {th }}$ Edition (full note)}

Tahap pelaksanaan merealisasikan tahap persiapan sesuai desain, dan tahap evaluasi menguji keefektifan tahap persiapan dan tahap pelaksanaan. ${ }^{1}$

${ }^{1}$ Novita Loma Sahertian et al., "Penerapan Model Pembelajaran Jerold E KEM Di Smp Hanuru," Jurnal Pendidikan Agama Kristen (JUPAK) 2, no. 1 (June 16, 2021): 1, accessed July 4, 2021, https://doi.org/10.52489/jupak.v2i1.26. 


\section{Endnote}

Endnote merupakan sumber kutipan yang memiliki dua letak yaitu disebelah setelah kutipan dan diakhir karangan. Jenis ini memperlihatkan nomor kutipan dan sumber kutipan (nama, judul, tempat publikasi, halaman, tahun dan url/doi). Berikut salah satu contoh style yang masuk dalam kategori Endnote.

\section{$\underline{\text { IEEE }}$}

Masalah adalah kesenjangan antara harapan dengan kenyataan.[1]

[1] J. R. Sirait, "Kajian Teologis tentang Metode Penyelesaian Masalah Pribadi Berdasarkan Surat Filemon 1:4-22," pp. 1-39, 2021, doi: 10.31219/OSF.IO/2NARW.

\section{Memasukan Bahan Rujukan Lewat Web dan Desktop}

Pada tahapan ini para penulis seringkali mengalami kebingungan. Hal ini dapat dimengerti karena Mendeley Web dan Desktop terpisah sehingga pada saat memasukan bahan rujukan lewat web, penulis masih tidak menemukan artikel atau jenis karya tulis tersebut di Mendeley Desktop. Para penulis berpikir jika memasukan hal tersebut lewat Web maka artikel secara otomatis ada pada Mendeley Desktop, pada hal mereka harus mengklik singkron di Mendeley Desktop baru artikel yang ada di Mendeley web dapat masuk ke versi Desktop. Berikut langkah-langkah memasukan bahan rujukan lewat versi web maupun desktop.

\section{Web dan Desktop}

Mendeley Web dan Desktop merupakan aplikasi yang terpisah namun keduanya terkoneksi. Para penulis dapat mencari bahan rujukan di Google Scholar atau tempat lainnya. Setelah mendapatkan, penulis harus mengklik gambar Mendeley yang terdapat pada halaman pojok kiri atas di Google Chrome. ${ }^{6}$ Selanjutnya penulis diminta terlebih dahulu untuk login menggunakan email dan password yang sudah didaftar, maka akan muncul pilihan artikel dan penulis haruslah menceklis artikel yang versi view PDF. Setelah

\footnotetext{
${ }^{6}$ Para penulis dapat menggunakan aplikasi lain seperti Mozilla Firefox.
} 
itu baru klik ADD. Setelah berhasil maka penulis harus membuka Mendeley Desktop dan mengklik sinkron. Pada tahapan ini artikel sudah ada dalam aplikasi Mendeley Desktop dan dapat dibuka melalui aplikasi tersebut.

\section{Melalui Mendeley Desktop}

Mendeley Desktop merupakan aplikasi yang memiliki fixture yang cukup lengkap. Penulis dapat menambangkan referensi dan sitasi hanya melalui aplikasi desktop tanpa melalui versi web. Namun, bagi penulis-penulis yang baru mempelajari aplikasi ini seringkali belum tahu bagaimana cara memasukkan artikel secara alternatif. Berikut ini empat cara memasukan bahan rujukan hanya menggunakan Mendeley Desktop.

\section{$\underline{\text { RefMan }}$}

Penulis dapat melakukan cara ini dengan mendownload RefMan yang kebanyakan diperoleh lewat Google Scholar. Setelah mendapatkannya, penulis dapat klik add, lalu mencari file yang telah di download, setelah menemukannya penulis dapat klik ok. Sampai saat ini bahan rujukan telah ada di Mendeley Desktop dan dapat digunakan untuk sitasi dan referensi.

\section{Memasukan Bahan Rujukan Secara Manual}

Pada bagian ini tidaklah sulit untuk melakukannya tetapi seringkali membuat para penulis menjadi kesal karena nama penulis dari artikel, buku, dan sejenisnya yang telah dimasukan hasilnya, tidak sesuai dengan yang semestinya. Pada bagian ini para penulis harus benar-benar memperhatikan cara menulis nama. Berikut ini tahapan-tahapan untuk memasukan artikel secara manual. Klik import additional documents to the current collection, pilih Add Entry Manually. Pilih sesuai dengan jenis karya tulis yang menjadi rujukan. Isi semua yang diminta dengan baik. Mengenai memasukan nama penulis, harus menulis nama depan terlebih dahulu dan beri tanda koma dan setelah itu berikan nama belakangnya. Pada tahapan ini sudah benar, tetapi sebelum klik ok, lebih baik dilihat kembali apakah ada kesalahan. Selain cara tersebut. Ada cara alternatif untuk memasukan 
artikel ke Mendeley Desktop dengan cara memasukan DOI pada halaman yang sudah ada lalu klik lookup. Pada bagian ini para penulis telah benar dalam pengoprasiannya.

\section{Membuat Sitasi}

Pada bagian ini penulis tidak akan membahas cara sitasi dari awal karena sudah di bahas di bagian-bagian sebelumnya. Penulis juga menganggap bahwa semua bahan rujukan telah dimasukan kedalam Mendeley Desktop. Berikut cara menambah sitasi. Pertama penulis diminta untuk membuka artikel di file word. Kedua, pilih menu referensi dan klik Insert Citation. Ketiga, pada bagian pencarian ketik judul yang menjadi bahan rujukan untuk di sitasi atau ketik nama pengarangnya, lalu klik nama pengarang tersebut dan isi nomor halaman yang akan disitasi, setelah itu klik ok.

\section{Membuat Referensi}

Membuat referensi adalah bagian yang sangat mudah bagi para penulis. Bagian ini merupakan langkah yang prosesnya sangat cepat dibandingkan dengan bagian-bagian yang lainnya. Berikut langkah untuk membuat referensi. Pilih menu referensi dan klik insert bibliography.

\section{Kesimpulan}

Aplikasi Mendeley merupakan program yang berfungsi untuk menolong para penulis dalam menambahkan sitasi dan referensi. Mendeley juga memudahkan para penulis untuk mencari kalimat-kalimat yang menjadi pendukung atau pijakan dari karya tulis yang sedang dikerjakannya. Para penulis yang masih sering mengalami kesalahan dalam menggunakan aplikasi ini atau yang sudah menyerah untuk menguasai aplikasi ini hanyalah dikarenakan tidak mengenal fixture-fixture yang terdapat pada Mendeley dengan baik dan kurang berusaha untuk mencari jalan dari permasalahan yang dialami di dalam media sosial. Melalui ketekunan dan niat, maka para penulis yaitu dosen dan mahasiswa akan menguasai aplikasi ini dengan baik dan tertolong dalam menyelesaikan segala tulisannya. 


\section{Biodata}

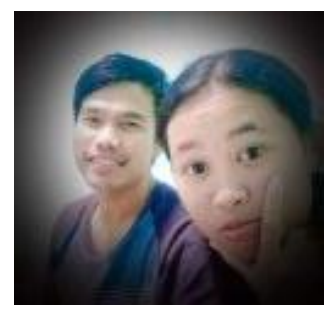

Junio Richson Sirait adalah staff Sekolah Tinggi Teologi Kadesi Yogyakarta yang dipercayakan dalam bidang researching and publishing. Dia juga mahasiswa pascasarjana prodi Magister Pendidikan Kristen dan guru di SMTK Kadesi Yogyakarta. Melalui tulisannya diharapkan dapat membantu banyak orang untuk mengembangkan kompetensi dalam dunia literatur.

\section{Junio Richson Sirait}

Surel : juniorichson1995@gmail.com

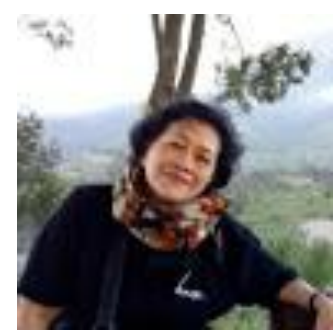

\section{Hestyn Natal Istinatun}

Surel: hestynistinatun@gmail.com

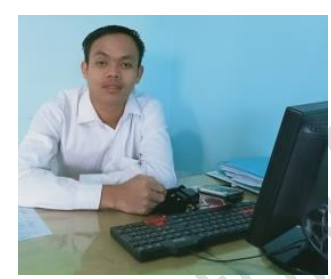

Marium adalah sekertaris prodi s1 Pendidikan Agama Kristen di Sekolah Tinggi Teologi Kadesi Yogyakarta. Dia juga mahasiswa pascasarjana prodi Magister Pendidikan Agama Kristen dan mengajar di SMTK Kadesi Yogyakarta. Melalui tulisannya diharapkan dapat memberkati banyak orang.

\section{Marium}

Surel: mariumaja4@gmail.com 


\section{Daftar Pustaka}

Jason Fitzpatrick (2021-08-19). "Mendeley Manages Your Documents on Your Desktop and in the Cloud".

Ristiono, Yosua Budi, and Junio Richson Sirait. "Refleksi Teologi Kovenan Berdasarkan Kejadian 1-3 Dan Implikasinya Bagi Kehidupan Orang Percaya Masa Kini." ejournal.sttkb.ac.id 1, no. 1 (2021): 186-200. Accessed August 20, 2021.

https://ejournal.sttkb.ac.id/index.php/kadesibogor/article/view/9.

Sahertian, Novita Loma, David Ming, Hestyn Natal Istinatun, and Junio Richson Sirait. "Penerapan Model Pembelajaran Jerold E KEM Di Smp Hanuru." Jurnal Pendidikan Agama Kristen (JUPAK) 2, no. 1 (June 16, 2021): 143-165. Accessed July 4, 2021. https://doi.org/10.52489/jupak.v2i1.26.

Sirait, Junio Richson. "Kajian Teologis Tentang Metode Penyelesaian Masalah Pribadi Berdasarkan Surat Filemon 1:4-22" (2021): 1-39. Accessed May 1, 2021. https://osf.io/2narw/.

https://id.wikipedia.org/wiki/Mendeley

https://id.wikipedia.org/wiki/Elsevier 